Egyptian Journal of Aquatic Biology \& Fisheries

Zoology Department, Faculty of Science,

Ain Shams University, Cairo, Egypt.

ISSN $1110-6131$

Vol. 24(2): 1 - 18 (2020)

www.ejabf.journals.ekb.eg

\title{
Effect of Copper on Hematological, Biochemical Changes and Reproductive Hormones of the Nile tilapia Oreochromis niloticus
}

\author{
Elsayed A. M. Shokr \\ Department of Physiology, Central Lab. for Aquaculture Research, Agriculture Research Center, Egypt \\ Professorelsayed99@gmail.com
}

\section{ARTICLE INFO}

\section{Article History:}

Received: Dec. 25, 2019

Accepted: March 7, 2020

Online: March 9, 2020

Keywords:

Copper;

Oreochromis niloticus;

antioxidant;

hematology;

biochemistry

\section{ABSTRACT}

The effect of copper concentrations on alterations in hematological and biochemical parameters as well as reproductive hormones of the Nile tilapia Oreochromis niloticus was investigated. The copper sulfate at sub-chronic concentrations 25,50 and $75 \mu \mathrm{g} / \mathrm{L}$ on Oreochromis niloticus for 90 days of exposure. Significant changes $(P<0.05)$ in almost all hematological aspects were found in the all groups exposed to different concentrations of copper 25,50 and $75 \mu \mathrm{g} / \mathrm{L}$ for 90 days. Biochemical analysis revealed various significant $(P<0.05)$ differences among the all groups that exposed to 25,50 and $75 \mu \mathrm{g} / \mathrm{L}$ of copper for 90 days of exposure. There was a significant difference in the copper concentrations in the tissues $(P<0.05)$ among all treated groups; in liver, gills and kidney. Glucose and cortisol in fish plasma increased significantly, while total protein and total lipids decreased significantly due to copper stress. The obtained results showed also that copper stress was harmful to the fish liver and kidney, where plasma aspartate aminotransferase, alanine aminotransferase, alkaline phosphatase, uric acid, and creatinine values were significantly increased with increasing exposure of copper on Oreochromis niloticus for 90 days compared to the control one. Plasma follicular stimulating hormones (FSH), 17ß estradiol (E2) and testosterone (T) were decreased significantly in fish with increasing exposure of copper concentrations. Among antioxidative enzymes, significant changes were revealed mainly in plasma ceruplasmin and glutathione reductase and glutathione peroxidase activity in liver and gills $(P<0.05$. The results demonstrate the deleterious influence of copper on Oreochromis niloticus, even at low doses. So, it is recommended to not use copper too much during treatment of the water that used in growing the fish.

\section{INTRODUCTION}

Copper $(\mathrm{Cu})$ is an essential micronutrient, with an either anti or pro oxidant properties Majewski et al., (2019). $\mathrm{Cu}$ is able to regulate superoxide dismutase (SOD), lysyloxidase and monoamine oxidase and is engaged in tryptophan metabolism by regulating the activity of enzymes on the kynurenine pathway Majewski, et al., (2016), which can generate toxic products when dysregulated (Majewski, et al., 2018). Recent studies have questioned the safety of the standard dosage of $\mathrm{Cu}$ looking for a possible alternative. Meanwhile, the beneficial antidiabetic and cardioprotective role of $\mathrm{Cu}$ nanoparticles (NPs) with decreased production of inflammatory mediators has been reported (Sharma, et al., 2018a; Sharma, et al., 2018b; Cholewińska, et al., 2018; Majewski et al., 2019; Sharma et al., 2016). copper can become highly toxic to living 
organisms. Copper contamination of the aquatic environment is of particular concern because organisms are continuously exposed via the skin and respiratory surfaces, as well as via the diet, including ingestion of contaminated water or sediment Wood et al., (2012). As a consequence of contemporary and historical mining activities, industrial processes and urban and agricultural runoff, copper concentrations currently reported in the aquatic environment often reach those known to be toxic to fish Batty et al., (2010). Copper can adversely affect multiple processes including branchial ion transport, haematopoiesis and glycolytic enzymatic activity, and cause immune suppression and oxidative stress Richards, (2009). In addition, fish exposed to copper have been shown to lose the ability to sense environmental oxygen levels Geest et al., (2002). This raises a significant concern as aquatic hypoxia and copper pollution often co-occur in the environment Malekpouri et al., (2016). Other studies investigating the combined effects of copper and hypoxia demonstrated that copper toxicity changed dramatically under hypoxic conditions during zebrafish (Danio rerio) development (copper toxicity was reduced during early development but increased in hatched larvae) Fitzgerald et al., (2016), with similar results observed for three-spined stickleback (Gasterosteus aculeatus) Fitzgerald et al., (2017). Combined exposures to copper and hypoxia also increased oxidative stress and caused alterations in blood parameters in the killifish (Fundulus heteroclitus) Ransberry et al., (2016), раси (Piaractus mesopotamicus) Sampaio et al., (2008) and carp (Cyprinus carpio) Mustafa et al., (2012). For mangrove rivulus (Kryptolebias marmoratus), exposure to copper induced hypoxia-like changes to gill morphology and increased the sensitivity of the hypoxia emersion response Blewett et al., (2017). In addition, for the common carp, a reduction in standard metabolic rate and critical oxygen level (Pcrit) was seen after combined exposure to copper and hypoxia Malekpouri et al., (2016). Copper is a transition metal with a high abundance in aquatic and terrestrial environments. Copper, as an essential nutrient, plays an important role in various functions in cellular biochemistry, especially as a cofactor for many enzymes and as a constituent of the non-enzymatic antioxidants ceruloplasmin and the metallothioneins Amiard et al. (2006). Through these mechanisms, copper participates in antioxidative defence against various deleterious substances Pandey et al. (2001). Copper at a dosage rate of $0.15-0.20 \mathrm{mg} / \mathrm{L} \mathrm{Cu}^{2+}$ is effective for control of important fish reported by Roy, (2010). Copper naturally occurs in fresh water systems in the concentration range from $0.5 \mathrm{mg} / \mathrm{l}$ Ruas $\boldsymbol{e t}$ al. (2008). One of the known mechanisms of copper toxicity to fish is the promotion of oxidative stress Lushchak, (2011). Direct oxidative damage to cells can be the result of the participation of copper in the production of reactive oxygen species through the Fenton reaction. Copper can interact with various antioxidant enzymes, particularly in acute exposures, or at the beginning of chronic exposure. Copper can also be bound to thiolcontaining molecules such as glutathione and metallothioneins Amiard et al. (2006), and thereby interfere with antioxidant defense. The aim of the present study was to investigate the impact of copper (copper sulphate) at slightly higher concentrations than environmental ones on Oreochromis niloticus for period 90 days of exposure. Furthermore, the study also focused on the difference in their effects on fish. The toxic impact was evaluated on the basis of results of hematological, biochemical and reproductive hormones and indices of oxidative stress. 


\section{MATERIALS AND METHODS}

\section{Experimental Design:}

Oreochromis niloticus body weight $(50 \pm 2 \mathrm{~g})$ were obtained from Abbasa fish farm. They were randomly distributed into twelve glass aquaria; each aquarium has $10 \mathrm{fish}$. Each treated group, including the control, was tested in triplicate. The control groups were subjected to dechlorinated tap water. The actual copper concentrations were measured on three different sampling days during the experiment, each time before and after bath renewal. The copper concentrations determined by atomic absorption spectrometry were $25.5 \pm 0.5,50.3$ \pm 0.7 and $75.6 \pm 0.9 \mu \mathrm{g} / \mathrm{l}$ for the groups exposed to copper sulphate (mean $\pm \mathrm{SEM})$. The experiment was conducted and siphoned every day. The control groups were subjected to dechlorinated tap water. For allgroups.

\section{Measurement of water quality:}

Water samples were collected at $20 \mathrm{~cm}$ depth from each aquarium. Dissolved oxygen and temperature were measured daily in site using a portable DO meter (Jenway, London, UK). The $\mathrm{pH}$ values were measured using a Digital Mini-pH Meter (model 55, Fisher Scientific, Denver, USA). The electric water conductivity was measured using a Portable Conductivity Meter (Jenway, London, UK). The unionized ammonia (NH3) concentration was measured using a Multiparameter Ion Analyzer (HANNA Instruments, Rhodes Island, USA). Total alkalinity and total hardness were measured by titration method according to Boyd (1984). In all treatments, water temperature ranged from 28 to $30{ }^{\circ} \mathrm{C}, \mathrm{pH}$ ranged from 7.5 to 7.6 , conductivity ranged from 51 to $52 \mathrm{uS} / \mathrm{cm}$, and unionized ammonia concentrations ranged from 0.10 to $0.12 \mathrm{mg} / \mathrm{L}$. Total alkalinity and total hardness ranges were $115-116$ and $240-241 \mathrm{mg} / \mathrm{L}$ as $\mathrm{CaCO} 3$, respectively. All the previous water quality parameters are within the acceptable range for fish growth. Tissue samples were removed (liver and gills) and stored at $-85^{\circ} \mathrm{C}$ until further analyses were performed. Whole livers were weighed prior to freezing. Fish growth were calculated as follows: Weight gain $(\mathrm{g})=$ final weight $(\mathrm{g})$ - initial weight $(\mathrm{g})$, Weight gain $\%=100$ [final weight $(\mathrm{g})$ - initial weight $(\mathrm{g})] /$ initial weight $(\mathrm{g})$, Condition factor $[\mathrm{CF}=($ weight $\times 100) /$ length 3 ] and Hepatosomatic index $[\mathrm{HSI}=($ liver weight/body weight $) \times 100]$. Tissue samples (liver, gills and muscle) were homogenized in $50 \mathrm{mM}$ potassium phosphate buffer with 1mM EDTA (pH 7.4). The homogenate was centrifuged at $5000 \mathrm{rpm}$ for 20 min at $4{ }^{\circ} \mathrm{C}$ and the supernatant was used for the determination of GR (glutathione reductase) and GPx (glutathione peroxidase) using a Bicinchoninic Acid Protein Assay Kit (SigmaAldrich, St. Louis, MO, USA) with bovine serum albumin as a standard The catalytic concentration of GR was determined by measuring NADPH (nicotinamidadeninedinucleotide phosphate-reduced) oxidation at $340 \mathrm{~nm}$ (Carlberg and Mannervik 1975). The catalytic concentration of GPx was calculated from the rate of NADPH oxidation in the reaction with GR at $340 \mathrm{~nm}$ (Flohe and Gunzler 1984). All these spectrophotometric methods were performed using a Varioskan Flash Spectral Scanning Multimode Reader (Thermo Scientific). Samples were measured using high performance liquid chromatography with electrochemical detection. The system consisted of two solvent delivery pumps operating in the range of $0.001-9.999 \mathrm{ml} / \mathrm{min}$ (Model 582 ESA Inc., Chelmsford, MA), a Zorbax eclipse AAA C18 $(150 \times 4.6 ; 3.5 \mu \mathrm{m}$ particle size; Agilent Technologies, USA), and a CoulArray elec- trochemical detector (Model 5600A, ESA, USA).

\section{Hematological and Biochemical parameters:}

Blood samples were taken at the end of experiment (90 days) from caudal vein and were stabilized with sodium heparin $(50 \mathrm{IU} / \mathrm{ml}$ of blood) for control fish and treated with copper sulfate at concentrations 25,50 and $75 \mu \mathrm{g} / 1$ for 90 days according to (Lebrun $\boldsymbol{e t}$ al. 2014 and Roy, 2010). Heparinized blood samples were used for the evaluation of 
hematological indicators, including erythrocyte count (RBCs), hemoglobin concentration (Hb), hematocrit (HCT), mean corpuscular volume (MCV), mean corpuscular hemoglobin $(\mathrm{MCH})$, mean corpuscular hemoglobin concentration (MCHC), leukocyte count (WBCs), and differential leukocyte count. Samples were processed according to Svobodova et al. (2012). The total leukocytes count were performed by the diluent/dye direct method outlined by (Natt and Herrick, 1952) in a Neubauer chamber at a dilution of 1:100. Following the total cell count of nucleated cells (leukocytes) in the Neubauer chamber. The packed cell volume was determined by the microhematocrit technique described by (Soivio and Oikari, 1976 and Jain 1986). Blood was used for erythrocyte count by (Dacie and Lewis 1984), hemoglobin content by Vankampen, (1961). Plasma samples were obtained after the centrifugation of blood (10000 rpm for $10 \mathrm{~min}$ at $4{ }^{\circ} \mathrm{C}$ ) and stored at $-85{ }^{\circ} \mathrm{C}$ until further analyses were performed. The analysed biochemical parameters included lactate dehydrogenase (LDH) and Plasma Ceruloplasmin was measured by (Ceron and Martinez 2004). The analysis was performed using a Varioskan Flash Spectral Scanning Multimode Reader (Thermo Scientific). Plasma cortisol levels were determined by radioimmunoassay by kits obtained from Bayer for assay, reagents and protocols which were described by (Pankhurst and Sharples 1992) were used. Plasma glucose concentration was measured according to Trinder, (1969), using Boehring Mannheium kits. Plasma protein content was determined by the Biuret method described by Wootton, (1964). Total lipids, cholesterol and triglycerides were determined calorimetrically using a kit supplied by El Nasr Pharmaceutical Chemical Co., according to Knight et al., (1972). Electrolytes using spectrophotometers. Creatinine, uric acid, ALP using methods of Britton, (1963). Aspartate aminotransferase (AST) and alanine aminotransferase (ALT) were determined calorimetrically using kits supplied by Diamond Diagnostics, according to (Reitman and Frankel, 1975). Determination of copper concentration in liver, gills, and muscle. $10 \mathrm{mg}$ of tissues were placed into glass vials and $700 \mu \mathrm{l}$ of nitric acid $(65 \%, \mathrm{w} / \mathrm{w})$ and $300 \mu \mathrm{l}$ of hydrogen peroxide (30\%, $\mathrm{w} / \mathrm{w})$ were added. The digestion of samples took place in a microwave system Multiwave 3000 (Anton-Paar $\mathrm{GmbH}$, Austria). Sample preparation for subsequent electrochemical measurements was as follows: $100 \mu \mathrm{l}$ mineralised sample were pipetted into Eppendorf tubes with $1900 \mu \mathrm{l}$ acetate buffer $(\mathrm{pH}=5.00)$. A blank digestion was simultaneously carried out in the same way. The determination of copper concentration by differential pulse voltammetry was performed with a 797 VA Computrace instrument connected to an 813 Compact Autosampler (Metrohm, Switzerland) using a standard cell with three electrodes. A hanging mercury drop electrode with a drop area of $0.4 \mathrm{~mm}^{2}$ was used as the working electrode. An $\mathrm{Ag} / \mathrm{AgCl} / 3 \mathrm{M} \mathrm{KCl}$ electrode was used as the reference and a platinum electrode as the auxiliary. The copper concentrations in fish tissues are given as $\mu \mathrm{g}$ per $\mathrm{g}$ of wet weight.

\section{Statistical analysis:}

The obtained data in this study were statistically analyzed for variance ANOVA, LSD (Least significant difference) according to (Snedecor and Cochran, 1982). Differences among treatment means were compared using Duncan's multiple range tests (Duncan, (1995). Data were presented as mean $\pm \mathrm{SE}$ and significance was declared at $(\mathrm{P}<0.05)$.

\section{RESULTS}

Growth changes in Oreochromis niloticus exposed to copper sulfate at concentrations 25, 50 and $75 \mu \mathrm{g} / \mathrm{L}$ for 90 days were observed at the highest concentration at the end of the experiment. Abnormal behavior included reduced food intake and reduced swimming activity. The mean values of growth indices are presented in Table 1. A significant increase ( $P$ $<0.05)$ in HSI was found in fish exposed to a copper concentration of 25,50 and $75 \mu \mathrm{g} / \mathrm{L}$. 
Condition factor, body weight, and Weight gain $(\mathrm{g})$ were significantly decreased $(P<0.05)$ at the copper concentrations of 25,50 and $75 \mu \mathrm{g} / \mathrm{L}$ compared to control groups.

Table 1. Effect of different copper concentrations on growth parameters of Oreochromis niloticus

\begin{tabular}{ccccc}
\hline Parameters & Control & $\mathbf{2 5} \boldsymbol{\mu g} / \mathbf{L}$ & $\mathbf{5 0} \boldsymbol{\mu g} / \mathbf{L}$ & $\mathbf{7 5} \boldsymbol{\mu g} / \mathbf{L}$ \\
\hline Initial weight $(\mathbf{g})$ & $50 \pm 3.2^{\mathrm{a}}$ & $50 \pm 3.5^{\mathrm{a}}$, & $50 \pm 2.2^{\mathrm{a}}$, & $50 \pm 1.2^{\mathrm{a}}$ \\
Final weight $(\mathbf{g})$ & $74.0 \pm 2.2^{\mathrm{d}}$ & $73.0 \pm 4.2^{\mathrm{c}}$ & $68.7 \pm 2.3^{\mathrm{b}}$ & $64 \pm 3.2^{\mathrm{a}}$, \\
Weight gain $(\mathbf{g})$ & $24.0 \pm 2.4^{\mathrm{d}}$ & $23 \pm 2.3^{\mathrm{c}}$ & $18 \pm 1.6^{\mathrm{b}}$ & $14 \pm 6.0^{\mathrm{a}}$ \\
Weight gain \% & $48 \pm 2.18^{\mathrm{d}}$ & $46 \pm 3.17^{\mathrm{c}}$ & $36 \pm 1.21^{\mathrm{b}}$ & $28 \pm 1.17^{\mathrm{a}}$ \\
Hepatosomatic & $3.77 \pm 0.09^{\mathrm{d}}$ & $3.40 \pm 0.08^{\mathrm{c}}$ & $2.89 \pm 0.08^{\mathrm{b}}$ & $2.41 \pm 0.11^{\mathrm{a}}$ \\
$\quad$ index & & & & \\
Condition factor & $2.32 \pm 0.03^{\mathrm{a}}$ & $2.23 \pm 0.04^{\mathrm{a}}$ & $2.2 \pm 0.04^{\mathrm{a}}$ & $2.2 \pm 0.03^{\mathrm{a}}$ \\
\hline
\end{tabular}

Data expressed as means $\pm \mathrm{SE}$, means with the same letter in the rows is not significant at $\mathrm{p}<0.05$

\section{Hematological parameters}

Hematological parameters of blood samples are presented in Table 2. It is obvious that Oreochromis niloticus exposed to copper sulfate at concentrations 25,50 and $75 \mu \mathrm{g} / \mathrm{L}$ for 90 days resulted in significant changes in almost all hematological aspects, especially in the group exposed to the highest concentration of copper. Erythrocyte count increased with copper concentration, with a significant $(P<0.05)$ difference between the highest concentration and control; hematocrit values exhibited a similar tendency. Leukocyte count decreased non-significantly with increasing copper concentration. Significantly less $(P<0.05) \mathrm{MCV}$ were found at the highest copper concentrations 25,50 and $75 \mu \mathrm{g} / \mathrm{L}$ compared with the control and with the $75 \mu \mathrm{g} / \mathrm{L}$ concentration. On the other hand, a significantly higher amount of $\mathrm{MCH}$, and $\mathrm{MCHC}$ at the 25,50 and $75 \mu \mathrm{g} / \mathrm{L}$ concentrations $(P<0.05)$ compared with the control.

Table 2. Effect of different copper concentrations on hematological changes of $O$. niloticus

\begin{tabular}{|c|c|c|c|c|}
\hline \multirow[t]{2}{*}{ Parameters } & \multirow[b]{2}{*}{ Control } & \multicolumn{3}{|c|}{ Doses of copper sulfate } \\
\hline & & $25 \mu \mathrm{g} / \mathrm{L}$ & $50 \mu \mathrm{g} / \mathrm{L}$ & $75 \mu \mathrm{g} / \mathrm{L}$ \\
\hline \multicolumn{2}{|c|}{$\operatorname{RBCs}\left(\mathbf{1 0}^{6} / \mathrm{mm}^{3}\right) 1.66 \pm 0.05^{\mathrm{a}}$} & $1.83 \pm 0.04^{\mathrm{a}, \mathrm{b}}$ & $1.97 \pm 0.05^{b, c}$ & $2.22 \pm 0.05^{\mathrm{c}}$ \\
\hline $\mathrm{Hb}(\mathrm{g} / \mathrm{dl})$ & $7.13 \pm 2.46^{\mathrm{a}, \mathrm{b}}$ & $8.14 \pm 1.98^{\mathrm{a}, \mathrm{b}}$ & $8.9 \pm 1.49^{a}, b$ & $9.5 \pm 4.72^{b}$ \\
\hline PCV (\%) & $28 \pm 0.01^{\mathrm{a}}$ & $29 \pm 0.01^{\mathrm{a}, \mathrm{b}}$ & $31 \pm 0.01^{b}$ & $34 \pm 0.01^{\mathrm{c}}$ \\
\hline $\operatorname{MCV}(\mu \mathrm{m} 3)$ & $122.3 \pm 3.9^{\mathrm{a}}$ & $114.63 \pm 4.2, b$ & $104.2 \pm 2.8^{c}$ & $103.4 \pm 5.1^{d}$ \\
\hline MCH (pg) & $42.3 \pm 2.96^{\mathrm{a}}$ & $45.6 \pm 1.4, \mathrm{~b}$ & $46.8 \pm 0.4^{\mathrm{c}}$ & $48.4 \pm 1.1^{\mathrm{d}}$ \\
\hline $\operatorname{MCHC}(\%)$ & $29.2 \pm 7.6^{\mathrm{a}}$ & $30 \pm 3.0^{\mathrm{b}}$ & $32 \pm 3.0^{\mathrm{c}}$ & $34 \pm 1.3^{\mathrm{d}}$ \\
\hline WBCs $\left(10^{3} / \mathrm{mm}^{3}\right)$ & $3.7 \pm 0.7^{\mathrm{d}}$ & $3.0 \pm 0.7^{b}$ & $2.2 \pm 0.8^{\mathrm{c}}$ & $2 \pm 0.5^{\mathrm{d}}$ \\
\hline
\end{tabular}

Data expressed as means $\pm \mathrm{SE}$, means with the same letter in the rows is not significant at $\mathrm{p}<0.05$

\section{Biochemical aspects}

The results of blood plasma biochemical indices are shown in Table 3 Significant $(P<$ 0.05) differences in total protein, phosphorus, calcium, glucose, triacylglycerol's, cholesterol, 
LDH and ALT were found among the tested groups. The activities of AST and ALP were significantly affected by copper exposure. Also, there were increased in plasma glucose, cortisol, cholesterol, triglycerides and LDH due to exposure to copper compared to control one as shown in Table 3.

Table 3. Effect of different Copper Concentrations on Biochemical Changes of Oreochromis niloticus

\begin{tabular}{|c|c|c|c|c|}
\hline \multirow[t]{2}{*}{ Parameters } & \multirow[b]{2}{*}{ Control } & \multicolumn{3}{|c|}{ Doses of copper sulfate } \\
\hline & & $25 \mu \mathrm{g} / \mathrm{L}$ & $50 \mu \mathrm{g} / \mathrm{L}$ & $75 \mu \mathrm{g} / \mathrm{L}$ \\
\hline Glucose (gl/l) & $63.51 \pm 0.13^{\mathrm{a}}$ & $74.44 \pm 0.21^{b}$ & $85.12 \pm 0.29 \mathrm{c}$ & $87.97 \pm 0.74^{\mathrm{d}}$ \\
\hline Cortisol (g/dl) & $14.2 \pm 0.01^{\mathrm{a}}$ & $15.4 \pm 0.01, b$ & $25.6 \pm 0.01^{\mathrm{c}}$ & $28.3 \pm 0.01^{\mathrm{d}}$ \\
\hline $\begin{array}{c}\text { Total protein } \\
\text { (g/l) }\end{array}$ & $1.32 \pm 0.01^{\mathrm{a}}$ & $1.24 \pm 0.01^{\mathrm{a}, \mathrm{b}}$ & $1.16 \pm 0.01^{b c}$ & $1.15 \pm 0.01 \mathrm{bc}$ \\
\hline $\operatorname{ALT}(\mathbf{u} / \mathbf{l})$ & $37 \pm 0.04^{d}$ & $43 \pm 0.04^{b}$ & $49 \pm 0.05^{\mathrm{c}}$ & $52 \pm 0.08^{d}$ \\
\hline $\operatorname{AST}(\mathbf{u} / \mathbf{l})$ & $27 \pm 0.13^{\mathrm{a}}$ & $34 \pm 0.07^{b}$ & $49 \pm 0.08^{c}$ & $51 \pm 0.10^{\mathrm{d}}$ \\
\hline $\operatorname{ALP}(\mathbf{u l} / \mathbf{l})$ & $51 \pm 0.09^{\mathrm{a}}$ & $55 \pm 0.08^{b}$ & $63 \pm 0.11^{\mathrm{c}}$ & $71 \pm 0.20^{\mathrm{d}}$ \\
\hline Uric acid (mg/dl) & $9 \pm 1.4^{\mathrm{a}}$ & $10 \pm 1.2^{\mathrm{b}}$ & $11 \pm 1.4^{\mathrm{c}}$ & $12 \pm 1.1^{\mathrm{d}}$ \\
\hline $\begin{array}{c}\text { Creatinine } \\
(\mathrm{mg} / \mathrm{dl})\end{array}$ & $0.25 \pm 0.1^{\mathrm{a}}$ & $0.27 \pm 0.1^{\mathrm{b}}$ & $0.29 \pm 0.1^{\mathrm{c}}$ & $0.34 \pm 0.2^{\mathrm{d}}$ \\
\hline $\begin{array}{c}\text { Cholesterol } \\
(\mathrm{mmol} / \mathrm{l})\end{array}$ & $3.54 \pm 0.15^{\mathrm{a}}$ & $3.89 \pm 0.11^{\mathrm{a}, \mathrm{b}}$ & $4.87 \pm 0.17^{c}$ & $4.91 \pm 0.18^{c}$ \\
\hline $\begin{array}{c}\text { Triacylglycerols } \\
(\text { mmol/l })\end{array}$ & $1.38 \pm 0.10^{\mathrm{a}}$ & $1.41 \pm 0.09^{a, b}$ & $2.1 \pm 0.1^{\mathrm{a}, \mathrm{b}}$ & $2.2 \pm 0.3^{a, b}$ \\
\hline LDH (mmol/l) & $32 \pm 0.06^{\mathrm{a}}$ & $42 \pm 0.05^{b}$ & $56 \pm 0.07^{c}$ & $78 \pm 0.08^{d}$ \\
\hline Lactate (mmol/l) & $1.6 \pm 0.09^{\mathrm{a}}$ & $2.1 \pm 0.09^{b}$ & $2.4 \pm 0.07^{\mathrm{c}}$ & $2.6 \pm 0.08^{d}$ \\
\hline $\begin{array}{c}\text { Phosphorus } \\
\text { (mmol/l) }\end{array}$ & $2.0 \pm 0.09^{a}$ & $2.2 \pm 0.09^{\mathrm{ab}}$ & $2.4 \pm 0.07^{b}$ & $2.6 \pm 0.08^{c}$ \\
\hline $\begin{array}{l}\text { Calcium } \\
(\mathrm{mmol} / \mathrm{l})\end{array}$ & $2.2 \pm 0.05^{\mathrm{a}}$ & $2.5 \pm 0.03^{a b}$ & $2.9 \pm 0.04^{b}$ & $3.5 \pm 0.13^{c}$ \\
\hline
\end{tabular}

Data expressed as means $\pm \mathrm{SE}$, means with the same letter in the rows is not significant at $\mathrm{p}<0.05$

\section{Accumulation of Copper concentration in tissues}

Accumulation of copper distribution in Oreochromis niloticus exposed to copper sulfate at concentrations 25,50 and $75 \mu \mathrm{g} / \mathrm{L}$ for 90 days tissues is shown in Table 4 . The highest copper content was measured in liver and the lowest in muscle in all tested groups, including the control. Significant differences $(P<0.05)$ between groups were found with respect to copper concentrations in liver, gills and kidney. Also, a significant change was found in muscle. 
Table 4. Effect of different Copper sulfate on accumulation of copper in tissues of Oreochromis niloticus

\begin{tabular}{|c|c|c|c|c|}
\hline \multirow{2}{*}{ Parameters } & \multirow[b]{2}{*}{ Control } & \multicolumn{3}{|c|}{ Doses of copper sulfate } \\
\hline & & $25 \mu \mathrm{g} / \mathrm{L}$ & $50 \mu \mathrm{g} / \mathrm{L}$ & $75 \mu \mathrm{g} / \mathrm{L}$ \\
\hline Liver & $144.4 \pm 4.2^{\mathrm{a}}$ & $166.2 \pm 3.4^{b}$ & $182.1 \pm 2.2^{c}$ & $221.7 \pm 11.8^{d}$ \\
\hline Gills & $44 \pm 3.1^{\mathrm{a}}$ & $67.0 \pm 1.0^{b}$ & $73.2 \pm 2.1^{c}$ & $75.8 \pm 3.2^{d}$ \\
\hline $\begin{array}{l}\text { Kidney } \\
\text { Muscle }\end{array}$ & $\begin{array}{l}27.1 \pm 2.0^{\mathrm{a}} \\
14.8 \pm 0.2^{\mathrm{a}}\end{array}$ & $\begin{array}{l}44.4 \pm 4.3^{\mathrm{b}} \\
31.1 \pm 1.5^{\mathrm{b}}\end{array}$ & $\begin{array}{l}55.9 \pm 1.1^{c} \\
37.4 \pm 1.2^{c}\end{array}$ & $\begin{array}{c}53.9 \pm 3.1^{\mathrm{c}} \\
36 \pm 3.1^{\mathrm{c}}\end{array}$ \\
\hline
\end{tabular}

Data expressed as means \pm SE, means with the same letter in the rows is not significant at $p<0.05$

\section{Measurement of antioxidants enzymes}

Plasma ceruloplasmin activity (A) (increase in absorbance per $\min \times 10000$ ) in Oreochromis niloticus exposed to copper sulfate at concentrations 25,50 and $75 \mu \mathrm{g} / \mathrm{L}$ for 90 days was significantly increased with increasing copper concentrations. The enzymatic activities of glutathione reductase (GR) and glutathione peroxidase (GPx) are shown in Table 5. GR and GPx activity in liver and gill were changed significantly after copper exposure. Where, GR and GPx increased significantly $(\mathrm{P}<0.05)$ with increasing copper concentration compared to control group.

Table 5. Effect of different Copper Concentrations on antioxidant enzymes of Oreochromis niloticus

\begin{tabular}{ccccc}
\hline Parameters & & \multicolumn{3}{c}{ Doses of copper sulfate } \\
& Control & $\mathbf{2 5} \boldsymbol{\mu g} / \mathbf{L}$ & $\mathbf{5 0} \boldsymbol{\mu g} / \mathbf{L}$ & $\mathbf{7 5} \boldsymbol{\mu g} / \mathbf{L}$ \\
\cline { 2 - 5 } Ceruloplasmin activity & $38.1 \pm 1.2^{\mathrm{a}}$ & $49.3 \pm 1.2^{\mathrm{b}}$ & $55.5 \pm 1.2^{\mathrm{c}}$ & $67 \pm 1.1^{\mathrm{d}}$ \\
$\quad \mathbf{n m o l} / \mathbf{m g}$ & & & & \\
Liver GR nmol/mg & $7 \pm 0.4^{\mathrm{a}}$ & $7.5 \pm 0.1^{\mathrm{a}, \mathrm{b}}$ & $8 \pm 0.7^{\mathrm{a}, \mathrm{b}}$ & $9 \pm 0.6^{\mathrm{b}}$ \\
Gills GRnmol/mg & $11 \pm 1.0^{\mathrm{a}}$ & $11.5 \pm 1.3^{\mathrm{a}, \mathrm{b}}$ & $12.5 \pm 1.2^{\mathrm{b}}$ & $13 \pm 1.1^{\mathrm{b}}$ \\
Liver GPx nmol/mg & $325.0 \pm 4.4^{\mathrm{a}}$ & $367.0 \pm 5.1^{\mathrm{b}}$ & $387 \pm 4.4^{\mathrm{c}}$ & $399 \pm 3.6^{\mathrm{d}}$ \\
Gills GPx nmol/mg & $77.1 \pm 4.0^{\mathrm{a}}$ & $97.1 \pm 2.3^{\mathrm{b}}$ & $115.7 \pm 2.2^{\mathrm{c}}$ & $129.9 \pm 4.1^{\mathrm{d}}$ \\
\hline
\end{tabular}

Data expressed as means $\pm \mathrm{SE}$, means with the same letter in the rows is not significant at $\mathrm{p}<0.05$

\section{Reproductive hormones}

Plasma levels of follicular stimulating hormone (FSH), 17ß-estradiol (E2) and testosterone (T) of Nile tilapia decreased significantly with the increase of copper concentrations levels lower than these of the control fish group (Table 6). 
Table 6. Effect of different copper concentrations on reproductive hormones of Oreochromis niloticus

\begin{tabular}{ccccc}
\hline Parameters & & \multicolumn{3}{c}{ Doses of copper sulfate } \\
& Control & $\mathbf{2 5} \boldsymbol{\mu g} / \mathbf{L}$ & $\mathbf{5 0} \boldsymbol{\mu g} / \mathbf{L}$ & $\mathbf{7 5} \boldsymbol{\mu g} / \mathbf{L}$ \\
\cline { 2 - 5 } FSH ng/ml & $9.3 \pm 21.8^{\mathrm{b}}$ & $7.8 \pm 0.2^{\mathrm{ab}}$ & $6 \pm 0.2^{\mathrm{a}}$ & $6 \pm 0.8^{\mathrm{a}}$ \\
$\mathbf{E} 2 \mathbf{~ n g / m l}$ & $17.0 \pm 0.4^{\mathrm{c}}$ & $12.0 \pm 0.1^{\mathrm{a}, \mathrm{b}}$ & $11.7 \pm 0.7^{\mathrm{a}, \mathrm{b}}$ & $10.4 \pm 0.6^{\mathrm{a}}$ \\
$\mathbf{T} \mathbf{~ n g} / \mathbf{m l}$ & $0.83 \pm 0.1^{\mathrm{c}}$ & $0.65 \pm 0.3^{\mathrm{bc}}$ & $0.55 \pm 0.2^{\mathrm{ab}}$ & $0.49 \pm 0.1^{\mathrm{a}}$ \\
\hline
\end{tabular}

Data expressed as means \pm SE, means with the same letter in the rows is not significant at $\mathrm{p}<0.05$.

\section{DISCUSSION}

The copper is important to biological functions; copper can be harmful to fish. The present study showed that chronic waterborne exposure to slightly higher copper concentrations than environmental ones could have negative effects on the health status of Oreochromis niloticus. Such effects include behavioral changes, the impairment of hematological and biochemical indices, an imbalance in antioxidant defense, and also pathological lesions in tissues. In connection with reduced food intake, in our study both body weight, hepatosomatic index and condition factor were reduced in fish exposed to copper at concentrations of 25,50 and $75 \mu \mathrm{g} / \mathrm{L}$ for 90 days. Lower body weight together with unchanged liver weight led to a reduced at the highest copper concentrations at 25,50 and $75 \mu \mathrm{g} / \mathrm{L}$ for 90 days. The liver is the main organ responsible for the maintenance of copper homeostasis and is also a possible target for copper induced damage in fish (Kamunde and McPhail 2008). the accumulation of copper in liver tissue is related to its concentration in the environment and the exposure time (Jezierska and Witeska 2001). Quantitatively speaking, food taken up through the intestine is the most important source of copper in fish Grosell, (2012). We registered a concentration dependent increase in copper content in liver, gills, and kidney. In contrast, copper content in muscle was not affected by exposure time; also, the copper concentration was lowest in muscle tissue compared with the other samples. Overall, we observed a copper distribution in tissues comparable to the findings of other studies (De Boeck $\boldsymbol{e t}$ al. 2004; Celechovska et al. 2007; Kandemir et al. 2010). In general, hematological indices can be influenced by a wide range of factors, both endogenous and exogenous (Nespolo and Rosenmann 2002). The hematological response is nonspecific towards chemical stressors; however, it can indicate that fish are exposed to environmental stress (Cazenave et al. 2005 and shokr, 2015). Changes in red blood cell profile are probably an adaptive response to the impairment of gas exchange in copper exposed gills and increased energetic demands on the fish Witeska et al. (2010). In the blood of fish under stress, an increase in erythrocyte counts, hemoglobin concentrations, and hematocrit levels are frequently observed. 
In our study, the increased erythrocyte counts and leucocytes, hematocrit values, $\mathrm{MCV}, \mathrm{MCH}$ and $\mathrm{MCHC}$ could be due to enhanced erythropoiesis as a result of chronic metal exposure (Kondera and Witeska 2013). The tendency towards a decreasing leukocyte count was not significant in the present study. The decrease in white blood cell count, as a sign of the suppression of nonspecific immunity, can be transient and gradually followed by a return to control levels, indicating an adaptive reaction of the organism. A decrease in lymphocytes together with a relative increase in neutrophil count is considered a common finding in the leukocyte profile of fish following exposure to copper and other metals (Jezierska and Witeska 2001). The plasma biochemical profile provides important information about the internal environment of the organism. An increased plasma glucose, cortisol, cholesterol, triglycerides, LDH and phosphorous and calcium concentrations, a commonly observed effect caused by various stress stimuli, was apparent in all tested copper concentrations. Initially, metals, including copper, activate glycogenolysis via increased secretion of catecholamines. Later, the gluconeogenic action of cortisol is apparent (Takei and Loretz 2006). Reduced insulin secretion, causing hyperglycaemia, was also described in fish after longterm exposure to copper Moon, (2001). An increase in plasma glucose, cortisol, cholesterol, triglycerides, LDH and phosphorous and calcium concentrations were documented by several authors in similar studies after the chronic exposure of various fish species to low copper concentrations (Heydarnejad et al., 2013 and Pretto et al., 2014). Disturbances in carbohydrate metabolism caused by metal intoxication may also be represented by changes in the accumulation of lactate and LDH activity (Teodorescu et al., 2012 and Perumalsamy and Arumugam 2013). Increased LDH activity was revealed at the highest copper concentrations 25,50 and $75 \mu \mathrm{g} / \mathrm{L}$ for 90 days; however, it was not accompanied by an increase in lactate level. Increased LDH activity is known to be a sign of anaerobic metabolism and is often a consequence of slight tissue damage in my study, the consequence of liver damage. On the other hand, the liver still retains the ability to scavenge lactate from plasma (Perumalsamy and Arumugam 2013). Cortisol, produced in fish under stress, stimulates protein metabolism, resulting in increased its levels De Boeck et al., (2001). Large amounts of ALT and AST are released into blood as a consequence of liver damage. In my study, the increase in ALT activity at the highest copper concentrations at 25,50 and $75 \mu \mathrm{g} / \mathrm{L}$ for 90 days might have been due to hepatocellular damage, which was revealed by histopathological examination of the tissue. These results are in accordance with those reported by many authors Shokr, (2015). Hepatobiliary disorder may also lead to decreased cholesterol clearance from blood and its elevated concentration in plasma, as was revealed at copper concentrations of 25,50 and $75 \mu \mathrm{g} / \mathrm{L}$ for 90 days. In fish, a unique glycoprotein, stanniocalcin, is produced by the so called Stannius 
corpuscules, which participates in the regulation of calcium levels Clark $\boldsymbol{e t}$ al., (2002). The increased calcium levels observed in my study could be due to the activation of pituitary gland hormones initiated by copper exposure. Ceruloplasmin serves as a copper transporter in blood and represents $90 \%$ of the total amount of copper in plasma (Di Giulio and Meyer 2008). Besides its transport function, ceruloplasmin possesses antioxidant properties through its ferroxidase activity and is involved in the homeostasis of iron and modulates the coagulation cascade Shukla et al., (2006). My findings on the dose dependent increase in ceruloplasmin levels confirmed the important role of ceruloplasmin in copper metabolism. My results are consistent with several other studies Tang et al., (2013). In Oreochromis niloticus, antioxidant enzymes have been shown to be either activated. Decreased GPx activities in liver were found in common carp 24 and $48 \mathrm{~h}$ after the intraperitoneal injection of copper $(10 \mathrm{mg} / \mathrm{kg}$ of body weight) Varanka $\boldsymbol{e t}$ al., (2001). In the present study, substantial changes were revealed in GR and GPX activities. A decline in GR and GPx activities at the highest copper concentration might be related to the inhibition of enzyme synthesis In my study, oxidative damage to lipids was probably a major cause of the morphological changes to hepatocytes. The present study revealed that decreased in the reproductive hormones in the fish exposed to different concentrations of copper may be due to decreased in food intake and decreased appetite of fish for food. Similar result reported by (Sydney and Volkoff, 2019) found larger eggs relative to body weight, compared to those with fewer or smaller eggs, suggesting that more mature females are more affected by fasting. Ryo, et al., (2018). confirmed that the variations in sex steroid hormone levels correlated with reproductive status in mature fish. Strongly suggest that E2 is an indicator for ovarian follicle development, and that $\mathrm{T}$ is a useful indicator for both the onset and end of the egg-laying period in fish. Also, Lucas, et al., (2019) showed is the first investigation of concurrent changes in reproductive, thyroid and adrenal hormone concentrations in this endemic and physiologically unique South American lizard. Findings set the stage for future investigations to determine the extent to which these hormones influence activity and thermoregulation in $S$. merianae. Steroid hormones were extracted from blubber and testosterone and estradiol are associated reproductive patterns in fish. The present result showed decreased in FSH, estradiol and testosterone agreement Sydney and Volkoff, 2019 who showed that the average body length, body weight and the reproductive hormones in the fish had the trend of annual variation. the reproductive hormone levels and the migratory reproductive activities are synchronized.

\section{CONCLUSION}

The present study provides further evidence that copper has a potentially deleterious effect on the fish organisms and is able to cause changes in biochemical and hematological aspects and enzymes of antioxidanta. The clearest changes were found 
at highst concentrated groups. Liver was the most affected organ, with disturbances even at the morphological level. The most sensitive biochemical parameter in the present study appeared to be glucose, cortisol, cholesterol, LDH, triglycerides, phosphorus and calcium, which were already affected at the lowest concentration (25 $\mu \mathrm{g} / \mathrm{L})$, whereas hematological indices, copper level in kidney, and selected oxidative parameters were influenced at concentrations of 50 and $75 \mu \mathrm{g} / \mathrm{L}$ for 90 days. These results concluded that total copper concentration played a greater role on the changes of fish activities for decreasing fish reproduction. So, from this study, it is recommended not to increase copper concentration in fish farms water, that certainly will cause the deterioration of the Nile tilapia health, which leads to its death.

\section{REFERENCES}

Amiard, J. C.; Amiard-Triquet, C.; Barka, S.; and Rainbow, J. (2006). Metallothioneins in aquatic invertebrates: Their role in metal detoxification and their use as bio- markers. Aquatic Toxicology, 76: 160-202.

Batty, L. C.; Auladell, M.; Sadler, J. and Hallberg, (2010). The impacts of metalliferous drainage on aquatic communities in streams and rivers. Ecology of Industrial Pollution. Cambridge Univeristy Press, Cambridge, pp. 70-100.

Blewett, T. A.; Simon, R. A.; Turko, A. J. and Wright, (2017). Copper alters hypoxia sensitivity and the behavioural emersion response in the amphibious fish Kryptolebias marmoratus. Aquat. Toxicol., 189: 25-30.

Boyd, B. S. (1984). Ethanol-Induced Inhibition of Chick Brain Growth Gerhard W. Kalmus PhD Sam N. Pennington PhD

Britton, C. j. (1963). Disorders of The Blood. 9.ed. London: J\&A Churchill. 332p.

Carlberg, I. and Mannervik, B. (1975). Purification and charac- terization of flavoenzyme glutathione reductase from rat liver. Journal of Biological Chemistry, 250: 5475-5480.

Cazenave, J.; Wunderlin, D.; Hued, A. and Bistoni, (2005). Haematological parameters in a neotropical fish, Corydoras paleatus (Jenyns, 1842) (Pisces, Callichthyidae), captured from pristine and polluted water. Hydrobiologia , 537: 25-33.

Celechovska, O.; Svobodova, Z.; Zlabek and Macharackova, (2007). Distribution of metals in tissues of the common carp (Cyprinus carpio L.). Acta Veterinaria Brno 76, S93 S100.

Ceron, J.; Martinez and Subiela, (2004). An automated spectrophotometric method for measuring canine ceruloplas- min in serum. Veterinary Research, 35: 671-679.

Cholewińska, E.; Juśkiewicz and Ognik, (2018a). Comparison of the effect of dietary copper nanoparticles and one copper (II) salt on the metabolic and immune status in a rat model. Journal of Trace Elements in Medicine and Biology, 48: 111-117. 
Cholewińska, E.; Ognik, K.; Fotschki, B.; Zduńczyk, Z. \& Juśkiewicz, (2018b). Comparison of the effect of dietary copper nanoparticles and one copper (II) salt on the copper biodistribution and gastrointestinal and hepatic morphology and function in a rat model. PLoS One, 13 (5): 70 - 83.

Clark, M. S.; Bendell, L.; Power, D. M.; Warner, S.; Elgar, G. and Ingleton, (2002). Calcitonin: characterisation and expres- sion in a teleost fish, Fugu rubripes. Journal of Molecular Endocrinology, 28: 111-123.

Dacie, J. V. and Lewis, S.M. (1984). Practical Hematology. 6.Ed. New York: Churchill. 22p.

De Boeck, A.; Vlaeminck, A.; Balm, M.; Lock, C.; De Wachter and Blust, B. (2001). Morphological and metabolic changes in common carp, Cyprinus carpio, during shortterm copper exposure: Interactions between $\mathrm{Cu} 2+$ and plasma cortisol elevation. Environmental Toxicology and Chemistry, 20: 374-381.

De Boeck, G.; Meeus, W.; Coen, W. and Blust, B. (2004). Tissue- specific Cu bioaccumulation patterns and differences in sensitivity to waterborne $\mathrm{Cu}$ in three freshwater fish: rainbow trout (Oncorhynchus mykiss), common carp (Cyprinus carpio), and gibel carp (Carassius auratus gi- belio). Aquatic Toxicology, 70, 179-188.

Di Giulio, R. and Meyer, T. (2008). Reactive oxygen species and oxidative stress. In: Di Giulio RT, Hinton DE (eds.): The Toxicology of Fishes. 1st ed. CRC Press, 273-325

Duncan, D. B. (1995). Multiple range and multiple F-tests. Biometrics, 11: 1-42.

Fitzgerald, J. A.; Jameson, H. M.; Dewar Fowler, V. H.; Bond, G. L.; Bickley, L. K.; Uren Webster, T. M.; Bury, N. R.; Wilson, R. J. and Santos, E. M. (2016). Hypoxia suppressed copper toxicity during early development in zebrafish embryos in a process mediated by the activation of the HIF signaling pathway. Environ. Sci. Technol., 50 (8): $4502-4512$.

Fitzgerald, J.; Katsiadaki, A. and Santos, (2017). Contrasting effects of hypoxia on copper toxicity during development in the three-spined stickleback (Gasterosteus aculeatus). Environ. Pollut., 222: 433-443.

Flohe, L. and Gunzler, A. (1984). Assays of glutathione per- oxidase. Methods in Enzymology, 105: 114-121.

Foster, L. B. and Dunn, R.T. (1974). Single-antibody technique for radioimmunoassay of cortisol in un-extracted serum or plasma. Chemistry, 20: 365-368.

Geest, H.; van der, G.; Soppe, W. J.; Greve, D.; Kroon and Kraak, A. (2002). Combined effects of lowered oxygen and toxicants (copper and diazinon) on the mayfly Ephoron virgo. Enviromental Toxicology and Chemistry, 21 (2): 431-436. 
Grosell, M. and Marshall, W., (2006). Ion transport, osmoregula- tion, and acid-base balance. In: Evans DH, Claiborne JB (eds.): The Physiology of Fishies. CRC Press, Taylor \& Francis, 177-230.

Grosell, M. (2012). Copper. In: Wood CM, Farrell AP, Brauner CJ (eds.): Homeostasis and Toxicology of Essential Met- als. 1st ed. Academic Press, Elsevier, 53-134.

Heydarnejad, M.; KhosravianHemami, M.; Nematollahi and A. Rahnama, (2013). Effects of copper at sublethal concentrations on growth and biochemical parameters in rainbow trout (Oncorhynchus mykiss). International Review of Hydrobiology, 98: 71-79.

Jain, N. C. (1986). Schalm's Veterinary Hematology. 4th ed. Lea and Febiger, 600. Washington square, Philadelphia, USA.

Jezierska, B. and Witeska, A. (2001). Metal Toxicity to Fish. 1sted. University of Podlasie, Siedlce, Poland. 318 pp.

Kamunde, C. and McPhail, R. (2008). Bioaccumulation and he- patic speciation of copper in rainbow trout (Oncorhynchus mykiss) during chronic waterborne copper exposure. Archives of Environmental Contamination and Toxicology, 54: 493-503.

Kandemir, S.; Dogru, M. I.; Orun, I.; Dogru, A.; Altas, L.; Erdogan, K.; Orun and Polat, C.(2010). Determination of heavy metal levels, oxidative status, biochemical and hematological parameters in Cyprinus carpio L., 1758 from Bafra (Samsun) fish lakes. Journal of Animal and Veterinary Advances, 9: 617-622.

Knight, J. A.; Anderson, S. and Rawle, J. M. (1972). Chemical Basis Of The SulfoPhosphoVanillin Reaction For Estimating Total Serum Lipids. Clin. Chem., 18: 199-202.

Kondera, E. and Witeska, M. (2013). Cadmium and copper reduce hematopoietic potential in common carp (Cyprinus car- pio L.) head kidney. Fish Physiology and Biochemistry, 39: 755-764.

Lebrun, J.; Uher, E.; TusseauVuillemin and Gourlay-France, M. H., (2014). Essential metal contents in indigenous gam- marids related to exposure levels at the river basin scale: Metal-dependent models of bioaccumulation and geo- chemical correlations. Science of the Total Environment, 466: 100-108.

Lucas, A. Z.; Kathleen, E.; Huntd Carlos, A.; Navasa and LorenBuckd, (2019). Seasonal changes in plasma concentrations of the thyroid, glucocorticoid and reproductive hormones in the tegu lizard Salvator merianae. General and Comparative Endocrinology, 273 (1): 134-143.

Lushchak, V. I., (2011). Environmentally induced oxidative stress in aquatic animals. Aquatic Toxicology, 101: 13-30.

Lushchak, I.; Bagnyukova, V.; Husak, V.; Luzhna, I.; Luschak, V.; Storey, K. (2005): Hyperoxia results in transient oxidative stress and an adaptive response by antioxidant 
enzymes in goldfish tissues. International Journal of Bio-chemistry and Cell Biology, 37: $1670-1680$.

Majewski, M. and Lebiedzińska, A. (2014). Variations of niacin content in saltwater fish and their relation with dietary RDA in Polish subjects grouped by age. Roczniki PZH., 65(2): 101-105.

Majewski, M.; Jurgonski, A.; Fotschki and Juskiewicz, (2018). The toxic effects of monosodium glutamate (MSG) - The involvement of nitric oxide, prostanoids and potassium channels in the reactivity of thoracic arteries in MSG-obese rats. Toxicology and Applied Pharmacology, 359: 62-69.

Majewski, M.; Kasica, A.; Jakimiuk, N. and Podlasz, A. (2018). Toxicity and cardiac effects of acute exposure to tryptophan metabolites on the kynurenine pathway in early developing zebrafish (Danio rerio) embryos. Toxicology and Applied Pharmacology, 341: 16-29.

Majewski, M.; Kozlowska, D.; Thoene, M.; Lepiarczyk and Grzegorzewski, (2016). Overview of the role of vitamins and minerals on the kynurenine pathway in health and disease. Journal of Physiology and Pharmacology, 67(1): 3-19.

Majewski, M.; Ognik, M. and Juśkiewicz, A. (2017). Effect of dietary copper nanoparticles versus one copper (II) salt: Analysis of vasoreactivity in a rat model. Pharmacological Reports, 69(6): 1282-1288.

Majewski, M.; Ognik, M. and Juśkiewicz, A. (2019a). The interaction between resveratrol and two forms of copper as carbonate and nanoparticles on antioxidant mechanisms and vascular function in Wistar rats. Pharmacological Reports, 71(5): 509-516.

Majewski, M.; Ognik, M. and Juśkiewicz, A. (2019b). Copper nanoparticles modify the blood plasma antioxidant status and modulate the vascular mechanisms with nitric oxide and prostanoids involved in Wistar rats. Pharmacological Reports, 71(3): 862-869.

Majewski, M.; Ognik, M. and Juśkiewicz, A. (2019c). Copper nanoparticles enhance vascular contraction induced by prostaglandin $\mathrm{F} 2$ alpha and decrease blood plasma $\mathrm{Cu} / \mathrm{Zn}$ ratio in Wistar rats. Journal of Elementology, 24 (3): 911-922.

Malekpouri, P.; Peyghan, A.; Mahboobi-Soofiani, R. and Mohammadian, N. (2016). Metabolic capacities of common carp (Cyprinus carpio) following combined exposures to copper and environmental hypoxia. Ecotoxicol. Environ. Saf., 127: 1-11.

Moon, T. W. (2001). Glucose intolerance in teleost fish: face or fiction? Comparative Biochemistry and Physiology B- Biochemistry and Molecular Biology, 129: 243-249.

Mustafa, S.; Davies, A. and Jha, J. (2012). Determination of hypoxia and dietary copper mediated sub-lethal toxicity in carp, Cyprinus carpio, at different levels of biological organisation. Chemosphere, 87: 413-422. 
Natt, M. P. and Herrick, C. A. (1952). A new blood diluent for counting the red and white blood cells of chickens. Poultry Science, 31: 335.

Nespolo, R. and Rosenmann, F. (2002). Intraspecific allometry of haematological parameters in Basilichthys australis. Journal of Fish Biology, 60: 1358-1362.

Pandey, S.; Ahmad, A.; Parvez, S.; Bin-Hafeez, B.; Haque and Raisuddin, B. (2001). Effect of endosulfan on antioxidants of freshwater fish Channa punctatus Bloch: 1. Protection against lipid peroxidation in liver by copper preexposure. Archives of Environmental Contamination and Toxicology, 41: 345-352.

Pankhurst, N. W. and Sharples, D.F. (1992). Effects of the capture and confinement onplasma cortisol concentrations in the snapper(Pagrusauratus), Australian Journalof Marine and Freshwater Research, 43:345-356.

Perumalsamy N. and Arumugam, V. (2 013). Enzymes activity in fish exposed to heavy metals and the electro-plating ef- fluent at sub-lethal concentrations. Water Quality Expo- sure and Health, 5: 93-101.

Pretto, A.; Loro, V. L.; Silva, V.; Salbego, J.; De Menezes, C.; Souza, D.; Gioda, R. and Baldisserotto, (2014). Exposure to sublethal concentrations of copper changes biochemistry parameters in silver catfish, Rhamdia quelen, Quoy and Gaimard. Bulletin of Environmental Contamination and Toxicology, 92:399-403.

Ransberry, V.; Blewett, E. and McClelland, A. (2016). The oxidative stress response in freshwater-acclimated killifish (Fundulus heteroclitus) to acute copper and hypoxia exposure. Comp. Biochem. Physiol. Part C Toxicol. Pharmacol., 179: 11-18.

Reitman, S. and Frankel, S. (1975). Colorimetric Determination of Glutamic Oxaloacetic and Glutamic Pyruvic Transaminase. J. Clin. Pathol., 28- 56.

Richards, J. G. (2009). Chapter 10 metabolic and molecular responses of fish to hypoxia. In: In: Richards, Jeffrey G., A. P. F, Colin, J.B. (Eds.), Fish Physiology Vol. 27. Academic Press, pp. 443-485.

Roy, P. and Yanong, E. (2010). Use of Copper in Marine Aquaculture and Aquarium Systems. This document is FA165, one of a series of the School of Forest Resources and Conservation, Program in Fisheries and Aquatic Sciences, UF/IFAS Extension, 165: 1 5 .

Ruas, G.; Carvalho, D.; De Araujo, H.; Espindola, E. and Fernandes, G. (2008). Oxidative stress biomarkers of exposure in the blood of cichlid species from a metal-contaminated river. Ecotoxicology and Environmental Safety, 71: 86-93.

Ryo, A.; Yanob, R.; Furuyamab, R.; Matsumotoab, and KeiichiSatoab, (2018). General and Comparative Endocrinology, 265 (1):174-179. 
Sampaio, F.; Boijink, G.; Oba, E. T.; Santos, L.; Kalinin, A. and Rantin, L. (2008). Antioxidant defenses and biochemical changes in pacu (Piaractus mesopotamicus) in response to single and combined copper and hypoxia exposure. Comp. Biochem. Physiol., 147: 43-51.

Sharma, A.; K. Kumar, A.; Sahu, M.; Sharma, G.; Datusalia, A. and Rajput, K. (2018a). Exercise preconditioning and low dose copper nanoparticles exhibits cardioprotection through targeting GSK-3 $\beta$ phosphorylation in ischemia/reperfusion induced myocardial infarction. Microvascular Research, 120: 59-66.

Sharma, A.; K. Kumar, A.; Sahu, M.; Sharma, G.; Datusalia, A. and Rajput, K. (2016). Synthesis and preliminary therapeutic evaluation of copper nanoparticles against diabetes mellitus and -induced micro- (renal) and macro-vascular (vascular endothelial and cardiovascular) abnormalities in rats. RSC Advances, 6: 36870-36880.

Sharma, A.; K. Kumar, A.; Sahu, M.; Sharma, G.; Datusalia, A. and Rajput, K. (2018b). Combined and individual strategy of exercise generated preconditioning and low dose copper nanoparticles serve as superlative approach to ameliorate ISOinduced myocardial infarction in rats. Pharmacological Reports, 70(4):789-795.

Shokr, E. A. M. (2015). Effect of Follicular Stimulating Hormone and Leutinizing Hormone on Reproduction, Physiological and Biochemical Changes of Oreochromis niloticus. Egypt. Acad. J. Biolog.Sci. (C. Physiology and Molecular Biology) 7(1):61-67.

Shokr, E.A.M. (2015). Effects of ammonium on blood contents of Oreochromis niloticus. Journal of Chemical and Pharmaceutical Research, 7(3): 1963-1968.

Shukla N.; Maher, S.; Masters, J.; Angelini, D. and Jeremy, G. (2006). Does oxidative stress change ceruloplasmin from a protective to a vasculopathic factor? Atherosclerosis, 187: $238-250$.

Snedecor, G. and Cochran, W. (1982). Statistical methods. 8th Ed., Ames. Lowa state university.

Soderberg, R. W. (1994). Flowing water fish culture. CRC Press, Boca Raton, 147.

Soivio, A. and Oikari, A. (1976). Haematological Effects Of Stress On A Teleost, Esox Lucis L. J. Fish Biol., 8: 397-411.

Sydney, L. and Volkoff, H. (2019). Effects of fasting on the central expression of appetiteregulating and reproductive hormones in wild-type and Casper zebrafish (Danio rerio). General and Comparative Endocrinology, 282 (1):113207- 113216.

Takei, Y. and Loretz, A. (2006). Endocrinology. In: Evans DH, Claiborne JB (eds.): The Physiology of Fishes. 3rd ed. CRC Press, Taylor \& Francis., 272-342.

Tang, Q.; Feng, L; Jiang, W.; Liu, Y.; Jiang, J.; Li, S. H.; Kuang, S. Y.; Tang, and Zhou, L. (2013). Effects of dietary copper on growth, digestive, and brush border enzyme 
activities and antioxidant defense of hepatopancreas and intestine for young grass carp (Ctenopharyngodon idella). Bio- logical Trace Element Research, 155: 370-380.

Teodorescu, D.; Munteanu, X.; Staicu, M. and Dinischiotu, A. (2012). Changes in lactate dehydrogenase activity in Car- assius auratus gibelio (L. Pysces) kidney, gills and intestine induced by acute exposure to copper. Romanian Biotechnological Letters, 17: $7873-7880$.

Trinder, P. (1969). Determination of Glucose in Blood Using Glucose Oxidase With An Alternative Oxygen Acceptor. Ann. Clin. Biochem., 6: 24-7.

Vankampen, E. J. (1961). Determination of Haemoglobin. Clin. Chem. Acta., 6: 538-44.

Varanka Z.; Rojik, X.; Varanka, I.; Nemcsok, J. and Abraham, J. (2001). Biochemical and morphological changes in carp (Cyprinus carpio L.) liver following exposure to copper sulfate and tannic acid. Comparative Biochemistry and Physiology C-Toxicology and Pharmacology, 128: 467-478.

Witeska, M.; Kondera, A.; Lipionoga, E. and Jastrzebska, J. (2010). Changes in oxygen consumption rate and red blood pa- rameters in common carp Cyprinus carpio L. after acute copper and cadmium exposures. Fresenius Environmen- tal Bulletin, 19: 115-122.

Wood, C.; Farrell, M. and Brauner, A. P. (2012). Homeostasis and Toxicology of Essential Metals, Vol. 31 Academic Press.

Wootton, L. I. (1964). Micro-Analysis. In: Medical Biochemistry In Micrometer 4.Ed. London: J\&A Churchill, 264pp. 


\section{ARABIC SUMMARY}

\section{تاثير النحاس على التغيرات الاموية و البيوكيميائية وهرمونات التكاثر للبطى النيلى}

\section{السيد احمد محمد شكر}

قسم بحوث الفسيولوجي، المعمل المركزي لبحوث الاسماك، مركز البحوث الزر اعية، مصر

تم در اسة تأثثر تركيزات النحاس على التغيرات في الدم والكيمياء الحيوية والهرمونات التناسلية للبلطي

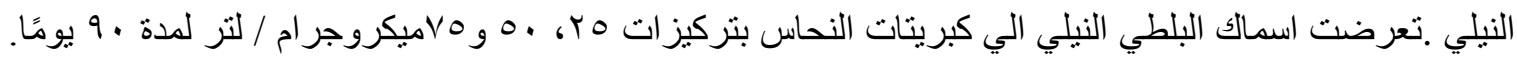

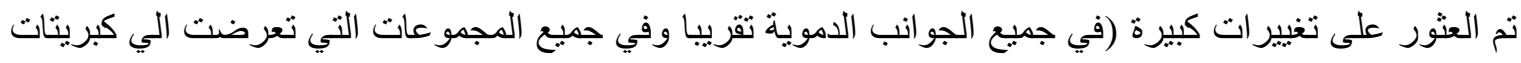

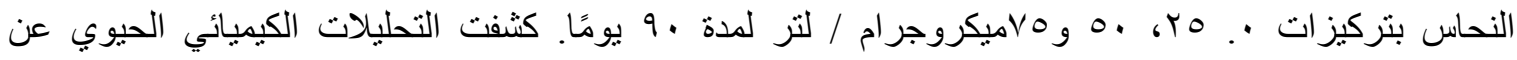

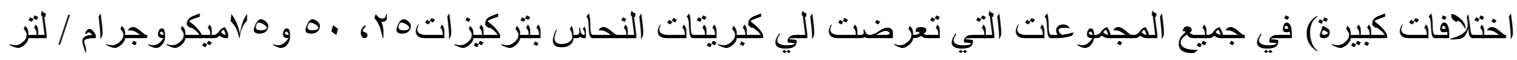

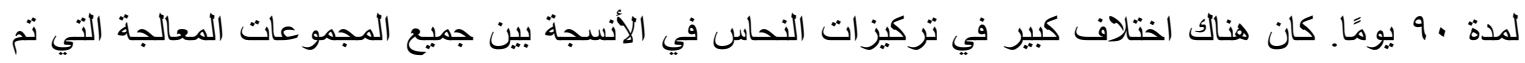

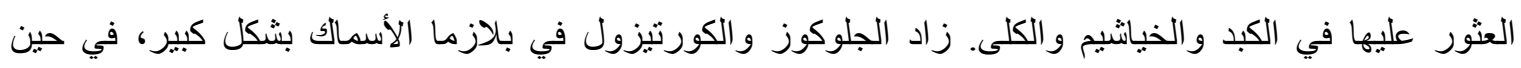

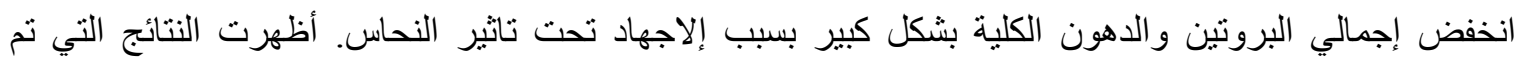

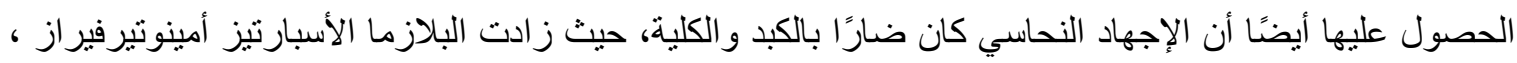

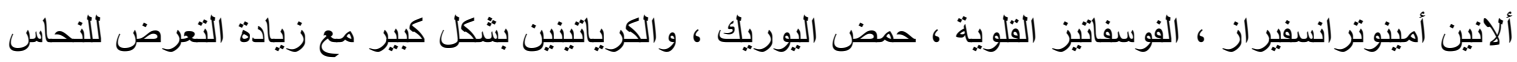

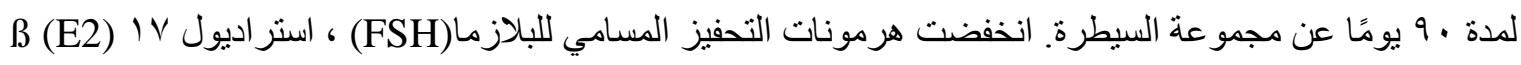

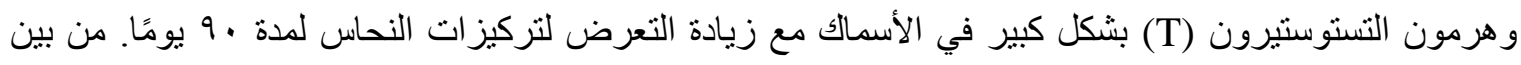
الإنزيمات المضادة للاككدة، تم الكثف عن نغييرات كبيرة بشكل رئيسي في سيروبلازمين البلازما وانزيم

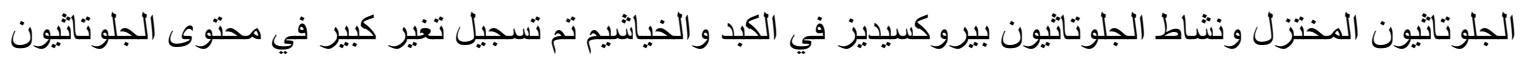

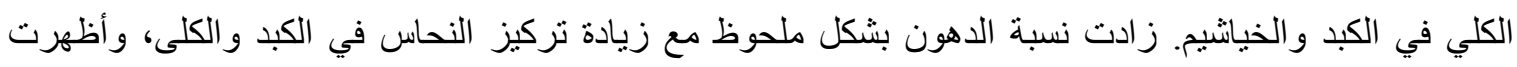

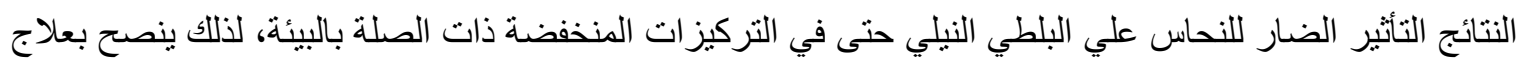

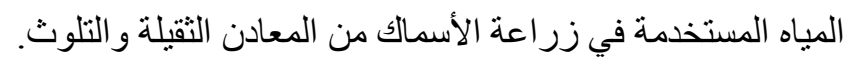

